\title{
A szexuális nevelésről orvosi szemmel a hazai adatok és a nemzetközi irányelvek tükrében
}

\author{
Varga-Tóth Andrea dr. ${ }^{1}$ - Németh Gábor dr. ${ }^{1}$ - Paulik Edit dr. ${ }^{2}$ \\ ${ }^{1}$ Szegedi Tudományegyetem, Általános Orvostudományi Kar, Szülészeti és Nőgyógyászati Klinika, Szeged \\ ${ }^{2}$ Szegedi Tudományegyetem, Általános Orvostudományi Kar, Népegészségtani Intézet, Szeged
}

Bevezetés: A fiatalkori szexualitás és az azzal kapcsolatos nemkívánatos következmények megelőzése világszerte probléma. Hazai és nemzetközi felmérések egyaránt kimutatták, hogy a serdülők egyre fiatalabb korban esnek át az első szexuális aktuson.

Célkitüzés: A kérdőíves felmérés és az interaktív szexuális oktatás során szerzett tapasztalatok, valamint a témához kapcsolódó nemzetközi irányelvek alapján annak meghatározása, hogy milyen módon és milyen ismeretek átadásával tudnak az orvosok - háziorvosok, házi gyermekorvosok, szülész-nőgyógyászok stb. - bekapcsolódni a fiatalok szexuális nevelésébe.

Módszer: A vizsgálat önkitöltéses, papíralapú kérdőíves felmérés formájában történt 13-18 éves általános, illetve középiskolás lányok $(\mathrm{N}=868)$ körében 2009 és 2016 között. A kutatás során serdülőkorú lányok szexuális aktivitását, fogamzásgátlással, szexuális úton terjedő fertőzésekkel kapcsolatos ismereteit, nőgyógyászattal (például rákszűrés) összefüggő tapasztalatait mértük fel nőgyógyász szakorvos által tartott szexuális oktatás előtt.

Eredmények: Minden 4 . lány már 14 évesen vagy korábban átesett az első szexuális aktuson, ugyanakkor szexuális ismereteik hiányosnak bizonyultak, és jelentős volt azoknak az aránya, akik ugyan éltek már szexuális életet, de még soha nem voltak nőgyógyászati vizsgálaton.

Következtetés: Az eredmények felhívták a figyelmet a reprodukciós élet oktatási, nevelési hiányosságaira, amelynek javítása összetett feladat, megoldásához szükség van a hazai egészségügyi és oktatási rendszer szemléletváltására, a tudományos bizonyítékokon alapuló irányelvek elfogadására, követésére. A szexuális nevelésben minden olyan egészségügyi dolgozónak részt kell vállalnia, aki a munkája során serdülókkel találkozik. Ugyancsak elengedhetetlen a szexuális nevelésnek az oktatásba való folyamatos beépítése, kisgyermekkortól egészen a fiatal felnőtt korig.

Orv Hetil. 2019; 160(13): 494-501.

Kulcsszavak: szexuális nevelés, fogamzásgátlás, szakmai irányelvek

\section{Medical aspects of sexual education according to national data and international guidelines}

Introduction: The prevention of early sexual life and its unwanted consequences is a worldwide problem. National and international surveys have shown that adolescents have their first sexual intercourse at a younger age.

Aim: The study aimed to determine the way of sexual education of young people provided by physicians - general practitioners, paediatricians, obstetricians, gynaecologists etc. - in accordance with the results of a questionnairebased study, the experiences gained during the interactive education and the suggestions of international guidelines dealing with sexual education.

Method: Self-administered questionnaire-based study was performed among 13-18-year-old girls attending primary or secondary school $(\mathrm{N}=868)$ between 2009 and 2016. The sexual activity of adolescent girls, their knowledge related to contraception and sexually transmitted infectious diseases, gynaecological (e.g., cancer screening) experiences were measured before sexual education performed by a gynaecologist.

Results: Every 4th girl had the first sexual act at the age of 14 or before, but at the same time their sexual knowledge was incomplete and there was a significant proportion of those who already have had sex but have never had a gynaecological examination.

Conclusion: The results highlighted the educational deficiencies of reproductive life, which is a complex task to solve, to address the changing approach of national healthcare and education systems, to adopt and follow scientific evi- 
dence-based guidelines. All health-care workers who are in contact with adolescents during their work must be involved in the sexual education. It is essential to continue incorporating sex education into education from early childhood to young adult age.

Keywords: sex education, contraception, practice guidelines

Varga-Tóth A, Németh G, Paulik E. [Medical aspects of sexual education according to national data and international guidelines]. Orv Hetil. 2019; 160(13): 494-501.

(Beérkezett: 2018. november 14.; elfogadva: 2018. november 26.)

\begin{abstract}
Rövidítések
$\mathrm{AAP}=($ American Academy of Pediatrics $)$ Amerikai Gyermekgyógyászati Akadémia; ACOG = (American College of Obstetricians and Gynecologists) Amerikai Szülészek és Nőgyógyászok Szakmai Kollégiuma; DMPA = (depomedroxyprogesterone acetate) depomedroxiprogeszteron-acetát; FDA = (U.S. Food and Drug Administration) az Amerikai Egyesült Államok Élelmiszer-biztonsági és Gyógyszerészeti Hivatala; HBSC = (Health Behaviour of School-aged Children) iskoláskorú gyermekek egészségmagatartása; HPV = humán papillomavírus; IUD = (intrauterine device) méhen belüli fogamzásgátló eszköz; IUS = (intrauterine system $)$ méhen belüli fogamzásgátló rendszer; KSH = Központi Statisztikai Hivatal; LARC = (longacting reversible contraception) hosszú távú reverzibilis fogamzásgátlási módszer; LNG = levonorgesztrel; LNG-IUS = (levonorgestrel-releasing intrauterine system) levonorgesztrel medikált méhen belüli eszköz; STD = (sexually transmitted disease $)$ nemi úton terjedő betegség; SZTE = Szegedi Tudományegyetem; $\mathrm{WHO}=($ World Health Organization $)$ Egészségügyi Világszervezet
\end{abstract}

A fiatalkori szexualitás és az azzal kapcsolatos nemkívánatos következmények - terhesség, fertőző betegségek stb. - megelőzése világszerte probléma, melynek megoldása multiszektoriális együttmúködést igényel az egészségügy, az oktatás, a nevelés, a család stb. részéről.

Hazai és nemzetközi felmérések egyaránt kimutatták, hogy a serdülők egyre fiatalabb korban - 13-14 évesen, sőt esetenként ennél is korábban - esnek át az első szexuális aktuson. Az iskoláskorúak körében végzett, 42 országot - így Magyarországot is - érintő HBSC-vizsgálat során a 15 éves tanulók 21\%-a (lányok 17\%, fiúk 24\%) számolt be arról, hogy már volt szexuális kapcsolata; a magyar fiatalok esetében jóval magasabbak voltak ezek az arányok (lányok 27\%, fiúk 29\%) [1]. Kiemelendő az is, hogy Magyarországon a 15 éves tanulók közül a szexuálisan aktív fiúk 48,8\%-a, a lányok 40,6\%-a 14 évesen vagy annál fiatalabban kezdte a szexuális életet [2]. A szexuálisan aktív tanulók által a leggyakrabban használt védekezési mód az óvszer önmagában vagy más módszerrel kombinálva volt, a szexuális életet élő tanulók 14,2\%-a viszont semmilyen módon nem védekezett [2].

A magyar serdülőkre jellemző korai szexuális élet következményeit a demográfiai adatok is tükrözik. Sedgh és mtsai (2015) 21 országra kiterjedő vizsgálata szerint Magyarországon volt a legnagyobb a 10-14 év közötti lányok terhességének aránya a 2011-es adatok alapján: ezer ilyen korú lányra 1,19 terhesség jutott, és ezek 60\%-a terhességmegszakítással végződött; az ezer 15-19 éves lányra jutó terhességszám 38 volt, a terhességmegszakítások aránya pedig 41\% [3]. A KSH 2016-os adatai szerint Magyarországon a fiatalkori terhességmegszakítások száma csökkenő tendenciát mutat ugyan, de a 19 évnél fiatalabb korosztályban regisztrált több mint 10 ezer terhesség egyharmada (a 10-14 éveseknél 63,4\%, a 15-19 éveseknél 36,2\%) terhességmegszakítással végződött [4].

A szexuális ismeretek hiánya, a nem megfelelő egészségmagatartás, -attitűd későbbi következményeire világítanak rá a méhnyakrák morbiditási és mortalitási adatai. A Nemzeti Rákregiszter (2014-es adatok) szerint az újonnan nyilvántartásba vett betegek száma 1161 volt [5]. A világ fejlett országaival összehasonlítva, Magyarországon igen magas a halálozás is, 2016-ban 396 fö halt meg méhnyakrákban [6], ugyanakkor - a 20-69 éves nők körében - a korai felismerésre irányuló szűrővizsgálat igénybevételi aránya $(35,9 \%)$ lényegesen elmaradt az Európai Unió átlagától $(63,0 \%)$ a 2014-es adatok szerint [7].

A szexuális nevelésre, ismeretekre vonatkozó hazai vizsgálatok [8,9] arra mutattak rá, hogy a fiatalok/serdülők rendelkeznek ugyan ismeretekkel a szexuális életről, de ezek sem mennyiségileg, sem minőségileg - tartalom és oktatási forma - nem felelnek meg az elvárásoknak. Jellemző, hogy ebben az életkorban nemcsak a védekezéssel kapcsolatos ismereteik hiányosak, de pszichés fejlődésük is elmarad fizikai érettségüktől. A 14 éves vagy annál fiatalabb korban elkezdett, védekezés nélküli szexuális élet mint kockáztató magatartás befolyással bír a későbbi egészségmagatartásra [10, 11].

A szexuális ismereteket közvetítő oktatásnak meghatározó szerepe van a fenti problémák - nem kívánt terhesség, későbbi daganatok prevenciója - megoldásában, mérséklésében. Jelenleg többféle formája létezik ugyan a szexuális felvilágosításnak, oktatásnak Magyarországon, de ezek eredményes volta megkérdőjelezhető. Az ismeretek elsődleges forrása általában a szülő, azután az iskola (tanárok, védőnő), a barátok, kortársak, legkevésbé az 
orvosok (háziorvos, nőgyógyász stb.). Az utóbbiak teljeskörúen nem is tudnák ezt felvállalni, de vannak területek (például a fogamzásgátlás), amelyeken a jelenleginél nagyobb szerepet kell kapniuk. Kutatásunk során serdülőkorú lányok szexuális aktivitását, fogamzásgátlással, szexuális úton terjedő fertőzésekkel kapcsolatos ismereteit, nőgyógyászattal (például rákszúrés) összefüggő tapasztalatait vizsgáltuk nőgyógyász szakorvos által tartott szexuális oktatás előtt. Célunk volt, hogy a kérdőívre adott válaszok, az interaktív oktatás során szerzett tapasztalatok és a témához kapcsolódó nemzetközi irányelvek (ACOG, AAP, WHO stb.) alapján meghatározzuk, hogy milyen módon és milyen ismeretek átadásával tudnak az orvosok - háziorvosok, házi gyermekorvosok, szülész-nőgyógyászok stb. - bekapcsolódni a fiatalok szexuális nevelésébe.

\section{Módszer}

\section{Vizsgált személyek}

Vizsgálatunkat önkitöltéses papíralapú kérdőíves felmérés formájában végeztük 13-18 éves általános, illetve középiskolás lányok $(\mathrm{N}=868)$ körében 2009 és 2016 között. A kitöltést követően - a SZTE Szülészeti és Nőgyógyászati Klinikájának gyermeknőgyógyászati szakrendelése keretében - a lányok szexuális ismereteket közvetítő oktatáson vettek részt; az előadást a klinika gyermeknőgyógyász szakorvosa tartotta.

A kérdőív a szociodemográfiai jellemzőkre, az egészségmagatartásra (szexuális magatartás, dohányzás), a fogamzásgátlással, méhnyakszűréssel, HPV-fertőzéssel kapcsolatos ismeretekre, az információszerzés módjára, valamint a nőgyógyászhoz fordulásra vonatkozó kérdéseket tartalmazott.

\section{Statisztikai elemzések}

Az adatok rögzítése és elemzése SPSS 24.0 programmal (IBM Corp., Armonk, NY, Egyesült Államok) történt. $\mathrm{Az}$ adatok elemzését leíró statisztikák (százalékos megoszlások, átlagok) és khi-négyzet-próba alkalmazásával végeztük. Az elemzés során a százalékos értékeket mindig az aktuálisan választ adókra vonatkozóan határoztuk meg. Az eredményeket $\mathrm{p}<0,05$ esetén tekintettük szignifikánsnak.

\section{Etikai engedély}

A vizsgálatot a Szegedi Tudományegyetem Regionális Humán Orvosbiológiai Kutatásetikai Bizottsága engedélyezte (az etikai engedély száma: 2418). Az oktatáson és az adatgyưjtésben való részvétel előzetes szülői beleegyezést követően történt; az adatokat anonim módon rögzítettük és dolgoztuk fel.

\section{Eredmények}

A felmérésben 868 fő vett részt. Az egészségnevelési előadások iránt jellemzően a 7-8. és a 9-10. osztályok érdeklődtek, amit az életkor szerinti megoszlás is mutatott, mely szerint a $14(27,4 \%)$ és a 15 évesek $(28,6 \%)$ dominanciája volt a jellemző (minimum 13 év, maximum 18 év). Iskolatípusonként közel azonos volt az arány: 261 fó $(30,1 \%)$ általános iskolába, 274 fó $(31,6 \%)$ szakközépiskolába és 333 fő $(38,4 \%)$ gimnáziumba járt.

A megkérdezettek több mint harmadának $(35,3 \%)$ volt már szexuális kapcsolata, a szexuálisan aktív lányok fele $(51,3 \%) 15$ évesen vagy annál fiatalabb korban létesítette az első kapcsolatát; 5,3\% 13 évesen, 18,1\% pedig 14 évesen (a szexuális életre vonatkozó kérdésre 3 fó nem adott választ). A legnagyobb arányban $(35,2 \%)$ a 16 éves kort jelölték meg a szexuális élet kezdetének; az első szexuális kapcsolat idejének átlagéletkora 15,35 $\pm 1,12$ év volt (minimum 13 év, maximum 18 év). A lányok 22,3\%-a vallotta magát dohányzónak (aktuálisan legalább napi egy szál cigarettát elszívott); a dohányzás prevalenciája az életkorral nőtt: a 13 éveseknél 4,7\%, míg a 15 éveseknél 17,4\%, a 18 évesek körében pedig 45\% volt. A dohányzás és a szexuális aktivitás korrelált egymással, a szexuálisan aktívak között szignifikánsan magasabb volt a dohányzás prevalenciája (48,5\% vs. $7,9 \%)$; ez a tendencia minden életkorban (évenként vizsgálva) megfigyelhetö volt.

Arra a kérdésre, hogy kapott-e szexuális felvilágosítást, a szexuális életet élók szinte teljes körben igennel válaszoltak, míg a többieknél némileg alacsonyabb volt az érték (98,0\% vs. 94,2\%). A szexuális ismeretek forrása leginkább a szülő, majd a védőnő, ezt követóen a barátok, a tanárok voltak; orvostól csak minden 5. lány kapott felvilágosítást.

A lányok szexuális élettel, prevencióval kapcsolatos ismereteit az 1. táblázat mutatja be a szexuális aktivitással összefüggésben.

A lányok 70\%-a hallott már a sürgősségi fogamzásgátlásról, a szexuális életet élők körében ez az arány meghaladta a 90\%-ot (1. táblázat). A sürgősségi fogamzásgátló tabletta használatával kapcsolatban - meddig érdemes bevenni - jelentős hiányosság mutatkozott mindkét csoportban. Azzal, hogy az első szexuális aktus során is szükség van védekezésre, a lányok 96,3\%-a tisztában volt. A fogamzásgátlásra vonatkozó kérdéseknél azt találtuk, hogy a szexuális életet élők tájékozottabbak ugyan, mint a szexuális életet nem élők, de még körükben is vannak hiányosságok (például a sürgősségi fogamzásgátló bevételének ideje).

A HPV terjedési módjára vonatkozó kérdésekre hibátlan választ mindössze egy kitöltő adott, többnyire $(84,0 \%)$ részben jó válaszokat kaptunk. A HPV terjedésének ismerete független volt a szexuális aktivitástól; a csókkal, a pettinggel, a nemi szervek bőrének érintkezésével történő terjedés lehetőségét $2,4 \%, 2,2 \%$, illetve $16,6 \%$ ismerte. Azt, hogy a gumi óvszer nem nyújt teljes 
1. táblázat |A szexuális élettel, prevencióval kapcsolatos ismeretek szexuális életet élő, illetve szexuális életet nem élő lányok körében

\begin{tabular}{|c|c|c|c|c|}
\hline \multirow[t]{2}{*}{ Ismeretek } & Szexuális életet él & $\begin{array}{l}\text { Szexuális életet } \\
\text { nem él }\end{array}$ & Összesen & \multirow[t]{2}{*}{ p-érték ${ }^{1}$} \\
\hline & $\mathrm{n}(\%)^{2}$ & $\mathrm{n}(\%)^{2}$ & $\mathrm{n}(\%)^{2}$ & \\
\hline Ismeri a sürgôsségi fogamzásgátlást & $284(93,1)$ & $316(57,4)$ & $600(70,1)$ & $<0,001$ \\
\hline $\begin{array}{l}\text { Pontosan tudja, hogy védekezés nélküli szexuális kapcsolat esetén } \\
\text { mennyi ideig érdemes bevenni a sürgősségi fogamzásgátló tablettát }\end{array}$ & $174(57,0)$ & $137(32,5)$ & $311(42,8)$ & $<0,001$ \\
\hline Tudja, hogy az első szexuális aktus során is szükség van védekezésre & $298(97,7)$ & $410(95,3)$ & $708(96,3)$ & 0,004 \\
\hline Teljesen vagy részben jól tudja, hogyan terjed a HPV & $245(81,4)$ & $445(85,6)$ & $690(84,0)$ & 0,220 \\
\hline $\begin{array}{l}\text { Tudja, hogy a gumi óvszer használata nem nyújt teljes védelmet a } \\
\text { HPV ellen }\end{array}$ & $76(25,0)$ & $188(36,4)$ & $264(32,2)$ & 0,001 \\
\hline Tudja, hogy a HPV-fertőzés kóros rákszűrési eredményt okozhat & $63(20,9)$ & $130(25,5)$ & $193(23,8)$ & 0,002 \\
\hline Ismeri, hogy melyik citológiai eredmény a kóros & $20(6,6)$ & $55(11,8)$ & $75(9,8)$ & 0,031 \\
\hline
\end{tabular}

${ }^{1}$ Khi-négyzet-próba eredménye.

${ }^{2}$ Azon lányok száma, illetve százalékos aránya a csoporton belül, akik rendelkeztek az adott ismerettel. A százalékos megoszlásokat az érvényes választ adók arányában adjuk meg, feltüntetve a kérdésre adott válaszra vonatkozó elemszámot is.

$\mathrm{HPV}=$ humán papillomavírus

körü védelmet a HPV-fertőzés ellen, csak minden harmadik megkérdezett tudta, ráadásul a szexuális életet élők tudása szignifikánsan rosszabb volt. Ugyancsak hiányosak voltak az ismeretek a HPV és a kóros rákszürési eredmény összefüggésére, valamint a kóros citológiai eredményre vonatkozóan. Kiemelendő, hogy az utóbbi két kérdésnél is a szexuálisan aktívak voltak kevésbé tájékozottak.

A nőgyógyászhoz fordulás kapcsán azt találtuk, hogy a teljes minta 30\%-a járt már életében nőgyógyásznál, ami önmagában nem jelent rossz arányt, viszont a szexuális életet élőknek is csak alig több mint a fele $(58,0 \%)$ volt már nőgyógyásznál, bár ez az arány szignifikánsan nagyobb $(\mathrm{p}<0,001)$, mint a szexuális életet nem élők körében talált érték (14,6\%).

\section{Megbeszélés}

Serdülőkorú lányok körében végzett vizsgálatunk eredményei más hazai felmérések adataihoz hasonlóan alakultak. Pénzes és mtsai [12] iskolások körében végzett kohorszvizsgálatuk során a rendszeres cigarettahasználat évről évre történő megduplázódását mutatták ki, amivel saját eredményeink is összhangban vannak (13 éveseknél a dohányzás prevalenciája 4,7\% volt, míg a 15 éveseknél már 17,4\%). A HBSC-kutatáshoz [2] hasonlóan azt találtuk, hogy jelentős azon lányok aránya, akik már 14 éves koruk előtt átestek az első szexuális aktuson. Ugyanakkor szexuális ismereteik (a HPV terjedése, fogamzásgátlás stb.) hiányosak, és jelentős azoknak az aránya, akik ugyan élnek már szexuális életet, de még soha nem voltak nőgyógyászati vizsgálaton. Eredményeink a szexuális, tágabb értelemben a reprodukciós élet ezen területének oktatási, nevelési hiányosságaira hívják fel a figyelmet.

Saját eredményeink mellett az élveszületések-terhességmegszakítások számára, a méhnyakrák okozta halálo- zásra, a szưrővizsgálatokon való részvételi arányra vagy a 2014 óta ingyenesen felvehető, HPV elleni védőoltás teljesítettségére vonatkozó kedvezőtlen statisztikai mutatóink is alátámasztják célkitüzésünk - a szexuális nevelés kiszélesítése, interdiszciplinaritásának növelése - aktualitását. Az, hogy a fiatalok megfelelő ismeretek birtokában kezdjék meg a szexuális életet, és egészségtudatos - biztonságos fogamzásgátlási módszert használó, a szûrővizsgálatokat igénybe vevő - felnőtté váljanak, többszöri, az életkornak megfelelő felvilágosítással érhető el. Éppen ezért szükség van a minél fiatalabb korban elkezdett szexuális tanácsadásra, különös tekintettel a fogamzásgátlással, a nőgyógyászati rákszűréssel, a szexuális úton terjedő betegségekkel, valamint a HPV elleni védőoltással kapcsolatos ismeretek bővítésére. Jelentős azoknak az aránya, akik 14 évesen vagy annál korábban élik át az első nemi aktust [2], ezért fontos, hogy - a korcsoport fejlettségének megfelelően - már az általános iskola alsó tagozatában el kell kezdeni a szexuális felvilágosítást, tágabb szemléleti keretû, életkészségeket fejlesztő programok keretében. Azt a tévhitet, hogy a nemiséggel kapcsolatos felvilágosító-oktató programok fokozzák a szexuális aktivitást, már több évtizede megcáfolta Kirby és Coyle (1997) harmincöt, szexualitással foglalkozó egészségfejlesztő programot összegző metaanalízise [13]. Ezt bizonyítja a serdülőkori terhességek egyesült államokbeli drasztikus csökkenése is 2011 után, amikor a kormány elkötelezte magát az iskolai prevenció mellett, szakítva az addigi „Abstinence-Only-Until-Marriage” („Önmegtartóztatás a házasságig”) elvvel (első típusú szexuális nevelés) [14-16].

A szexuális nevelés történetét röviden áttekintve láthatjuk, hogy Magyarország az európai országoktól lényegesen elmaradt. A második világháború utáni időszaktól egészen az 1970-es évek elejéig az egészségnevelés kizárólag felvilágosító jellegű volt, leginkább a 
személyi higiénéhez kapcsolódó témákra fókuszált. Majd az aktuális népesedéspolitikai elvekkel összhangban előírták a pedagógusoknak az általános iskola felsó osztályaiban a „családi életre nevelés” tematikájú órák tartását. Ehhez azonban segítséget nem kaptak, és a feladat végrehajtását sem ellenőrizték, megjelentek viszont az első anatómiai ismereteket tartalmazó középiskolai biológiai tankönyvek [17].

A mai általános iskolai tanmenetnek része ugyan az erkölcstan oktatása, mely részletesen foglalkozik a dohányzás, az alkohol és a droghasználat témakörével, de csak csekély mértékben érinti a szexualitást és a szexuális egészséget. A jelenleg érvényben levő, az oktató-nevelő munkát szabályozó Nemzeti Alaptanterv [18] fejlesztendő területként jelölte meg a családi életre nevelést („A köznevelési intézményeknek ezért kitüntetett feladata a harmonikus családi minták közvetítése, a családi közösségek megbecsülése. A felkészítés a családi életre segítséget nyújt a gyermekeknek és a fiataloknak a felelős párkapcsolatok kialakításában, ismereteket közvetít a családi életükben felmerülő konfliktusok kezeléséről. Az iskolának foglalkoznia kell a szexuális kultúra kérdéseivel is”). Az 5-6. osztályokban a természetismeret, a 7-8. osztályokban a biológia oktatásának keretében nevesítve van ugyan a „szaporodás, egyedfejlődés, szexualitás” mint témakör, de a pedagógusok maguk dönthetnek az oktatás részleteiről, a tematikáról, az alkalmazott módszerről és a számonkérés formájáról.

Európában először Svédország vezette be 1955-ben az iskolai keretek közötti kötelező szexuális oktatást, melyet Németország, Ausztria, Hollandia és Svájc is követett a következő évtizedekben. Az ezredfordulóra csatlakozott több más európai ország is, 2003-ban még a vallásos Î́rország is $[17,19,20]$.

Ha az egészségtudomány/orvostudomány felől közelítünk a kérdéshez, akkor megállapíthatjuk, hogy a pszichoszexuális nevelés égetô szükségességével kapcsolatban azok a szakirányok (pszichológusok, nőgyógyászok, gyermeknőgyógyászok, bőrgyógyászok) hallatják a leginkább a hangjukat, ahol a legtöbb fiatalkorú, bajba jutott páciens megfordul. Szükség lenne nemcsak a negatív oldalt (nem kívánt terhesség, abortusz, nemi betegség, következményes meddőség stb.) bemutató második típusú szexuális nevelés bevezetésére, hanem olyan holisztikus (harmadik típusú szexuális nevelés) megközelítésre is, amely tudományosan megalapozottan és az életkornak megfelelóen segíti a fiatalokat a belső harmónia és a felelős, tudatos életvezetési készség (barátság, család, szülői szerep stb.) elsajátításában [21, 22].

Tapasztalataink és az irodalmi adatok alapján is kimondhatjuk, hogy a serdülők 14 éves korukra már rendelkeznek a nemi szervek felépítésére és múködésére, a hormonális és idegrendszeri sajátosságokra vonatkozó legfontosabb ismeretekkel, míg sokkal kevésbé tájékozottak a fogamzás természetes módjáról, a fogamzásgátlásról és a szexuális úton terjedő betegségekről. Ezért nagy szükség lenne arra, hogy ezeket az ismereteket már kisgyermekkortól kezdve átadjuk az életkoruknak megfelelően. A holisztikus szemlélet alapja az, hogy a nemi nevelés a megszületéssel elkezdődik. Az első években a szülők szerepe elsődleges, de a közösségbe kerüléssel a bölcsőde, óvoda, iskola feladatai közé is kellene, hogy tartozzon ezen készségek további fejlesztése szervezett, kontrollált keretek között, mely tudományos alapokon nyugszik, az életkornak megfeleló, a tananyagba beépített. A WHO 2010-ben kiadott „Az európai szexuális nevelés irányelvei" címú ajánlása részletesen, korosztályokra lebontva taglalja a megfelelő ismereteket [22].

Napjainkban megváltozott a tizenéves terhességek szerepe a szülészeti eseményekben, a bekövetkezett terhességek között magas a múvi vetéléssel végződők aránya (minden 3. terhesség). Azoknál a fiatalkorúaknál, akik már átestek valamilyen szülészeti eseményen (abortusz, szülés), egy következő nem kívánt terhesség valószínűsége lényegesen nagyobb $[4,23]$.

Korábbi a biológiai érettség és az első szexuális kapcsolat, későbbi életkorban következik be a gyermekvállalás. Kinyílt az olló az első szexuális kapcsolat és az első gyermekvállalás életkora között. Egyre több idő telik el fogamzásgátlással, ezért nagyon fontos, hogy egyénre szabottan történjen meg a fogamzásgátlási tanácsadás. Serdülőkorban bármilyen rosszul megválasztott fogamzásgátlási módszer jobb, mint egy nem kívánt terhesség, de lehetőségeinkhez képest törekedjünk a serdülő számára legtökéletesebb módszer kiválasztására.

A nőgyógyász/gyermeknőgyógyász feladata nem csak a betegségek diagnosztizálása és kezelése, hanem elsődleges, legfontosabb céljai közé tartozik a megelözés [24, 25]. Az egészségnevelés szempontjából, a serdülők közül a legfogékonyabb csoportot képezik a gyermeknőgyógyászati szakrendelésen megjelenők. Itt hatékonyabban lehet fellépni a fiatalkori nem kívánt terhességek és a szexuális úton terjedő betegségek ellen. A fogamzásgátlás hiánya visszavezethető a hiányos felvilágosításra, az óvszer helytelen használatára, a sürgősségi fogamzásgátló nem kellő ismeretére és annak beszerzési nehézségeire, továbbá a szülőktől, a meddőségtôl, a mellékhatásoktól való félelemre is és nem utolsósorban sokszor financiális okokra.

Fontos megemlíteni, hogy ebben a korosztályban lényegesen nagyobb a felhasználótól függő hiba is, ezért nagyobb biztonságot adnak a hosszú távú reverzibilis fogamzásgátló módszerek, melyek alkalmazása nem függ a felhasználótól, mint azok, amelyek esetében a serdülő aktív tevékenysége szükséges (rövid távú fogamzásgátlási módszerek) [26-29].

A szülész-nőgyógyász, gyermeknőgyógyász feladatai közé tartozik a fiatalok felvilágosítása, a fogamzásgátlás szükségességének hangsúlyozása a nem kívánt terhességek számának csökkentése érdekében, a nemi úton terjedő betegségek megelőzésének lehetőségeiről való tájékoztatás $[21,30]$.

A fogamzásgátlási módszer kiválasztásakor a szakmai szempontok mellett [28] figyelembe kell vennünk a pá- 
ciens lehetőségeit, kívánságait, a szülővel való kapcsolatát is. Fontos, hogy ismerjük az újdonságokat, részletes tájékoztatást is adjunk ezekről a serdülő számára érthető módon, és lehetőség szerint beszéljünk négyszemközt is a fiatallal [31].

A választáskor legyünk tekintettel az életkorra, a menstruációs ciklusra, a menstruációs panaszokra, a krónikus betegségekre, az állandó gyógyszerszedésre, a családi anamnézisre és legfőképpen a serdülő és a szülő elvárásaira [28]. A Good Contraceptive Counselling Practice („teljes körü fogamzásgátlási tanácsadás”) elve alapján kérdezzünk rá a páciens ismereteire, igényeire, félelmeire. Ismertessük meg vele az orvosi javallatokat és ellenjavallatokat, nevezzük meg az összes elérhető módszert. Tájékoztassuk a módszerek előnyeiről és hátrányairól, és el kell fogadnunk az elutasító választ is [32]. A döntést (választást) az orvosi indokok és az egyéni prioritások mentén kell meghozni [30, 31].

Világszerte egyre jobban terjed a már fiatalkorúaknál is használható hosszú távú reverzibilis fogamzásgátlási (LARC-) módszerek alkalmazása, melyek közé a DMPA-t (az FDA feketedobozában szerepel), a bőr alá helyezhetô implantátumot (Magyarországon nem érhető el), az IUD-t és a levonorgesztrel medikált intrauterin eszközt (LNG-IUS) soroljuk. Míg 20 évvel ezelőtt világszerte elfogadott nézet volt, hogy nem szült nőknél a méhen belüli fogamzásgátló eszközöket nem javasoljuk, addig mára már a serdülőknél is az elsőként választandó módszerként tartjuk számon biztonsága és megbízhatósága alapján. Számos érvényben lévő hazai és külföldi állásfoglalás, irányelv nyilatkozik a LARC-módszerekről és ajánlják az első választandó módszerként a fiatalok és a nem szült nők körében is [28, 29, 33-36].

A „Contraceptive CHOICE Project” bizonyította, hogy ha ingyenesen választható bármelyik fogamzásgátlási módszer, akkor a nők többsége a LARC- (70\%) módszer mellett dönt. A 18 és 20 év közötti fiatalok az IUD-t, míg a legfiatalabbak (14-17 év) az implantátumot választották [37]. Második tanulmányukban két év távlatában azt vizsgálták, hogy a LARC és non-LARC fogamzásgátlási módszerek használatának folytatólagossága milyen mértékü; a LARC-módszert 77\%-ban, míg a non-LARC-módszert 41\%-ban folytatták [38]. Hasonló eredményt mutatott a LNG-IUS-t használó fiatalok körében végzett tanulmány is, ahol 16,8\% volt az egy éven belül a módszert abbahagyók aránya. Ez a tanulmány is bizonyította, hogy a fiatalok körében biztonságos a LNG-IUS használata [39, 40].

Tekintettel arra, hogy Magyarországon az implantátum nem érhető el, a DMPA-t csak kivételes esetben használjuk, a LARC-módszerek közül az IUD és a LNGIUS módszerek használata lehetséges.

Kétségeink/félelmeink eloszlatásában (kismedencei gyulladás, vérzészavar, nem kívánt terhesség, meddőség stb.) segít a Szakmai Kollégium Szülészeti-Nőgyógyászati és Asszisztált Reprodukciós Tagozatának módszertani levele: Méhen belüli fogamzásgátlás még nem szült nőknél [26], és emellett több külföldi tanulmány is. Külön irodalmat találunk a LARC-módszerre alkalmas páciens kiválasztásáról, az IUD/medikált IUS felhelyezésének körülményeiről, arról, hogy a rutinszerü profilaktikus antibiotikus kezelés nem indokolt, de a szexuális anamnézis alapján a pácienseket kategorizálva a szükséges STD-szürést el tudjuk végezni [36, 40-45].

Megkülönböztetett figyelmet kell fordítanunk azokra a fiatalokra, akik terhességmegszakításon estek át vagy gyermeknek adtak életet, hogy még a terhesség, illetve a kórházi kezelés alatt kapjanak tájékoztatást a további biztonságos fogamzásgátlásról $[28,35,46]$.

Hazai viszonylatban nagy probléma, hogy a gyermeknőgyógyásznál való megjelenés többnyire egyenlő a már bekövetkezett nem kívánt terhességgel vagy már meglévő panaszokkal, szexuális úton terjedő betegséggel. Ezért szükség lenne az egészségügy valamennyi területén, de elsősorban a házi gyermekorvosoknál megjelenő serdülőkorúak felmérésére a szexuális élet szempontjából [47].

Kiemelendő, hogy az orvoshoz forduló fiatalok többsége eleve stresszhelyzetként éli meg a szexuális élettel kapcsolatos kommunikációt, ezért nagyon fontos, hogy soha ne ítélkezzünk, ne fejezzük ki rosszallásunkat, és mindig az adott helyzetnek megfelelően próbáljunk segíteni, útbaigazítást adni. Javasoljuk, hogy a magyarországi gyermekháziorvosi praxisokban is terjedjen el a preventív szemlélet, a szexualitásról, fogamzásgátlásról szóló konzultáció $[33,35,47,48]$ és még idejében a szakemberhez való irányítása ezeknek a serdülőknek. A háziorvosát már ismeri a fiatal, bizalmi kérdésekben lehet, hogy hamarabb nyílik meg, könnyebben megoszt olyan információt is, melyet még a szülei sem tudnak. Egy-egy ártalmatlan kérdés (például „Van-e már barátod?”) kapcsán a fogamzásgátlás és a szexuális úton terjedő betegségek kérdésköre is előkerülhet. Fontos a szexuális előélet megismerése is. Fel kell hívni a fiatalok figyelmét arra, hogy a szexuális élet megkezdésével nőgyógyászati szempontból két nagyon fontos kérdés merül fel. Az egyik a nem kívánt terhesség lehetôsége, a másik a méhnyakrák és a szexuális úton terjedő betegségek megelőzése.

Tájékoztatni kell őket arról is, hogy ezt követően minden évben szükség van nőgyógyászati [25], lehetőség szerint gyermeknőgyógyászati szakvizsgálatra, ahol a szakember a páciens állapota alapján dönti el, hogy milyen jellegű vizsgálatot kell elvégezni. A nőgyógyászhoz fordulás, a fogamzásgátlási tanácsadás nem kell, hogy feltétlenül fizikális (bimanuális) vizsgálatot jelentsen (félelmek leküzdése), a terhesség kizárására a vizelet terhességi teszt is alkalmas [49], de a szexuális életet élők éves vizsgálata egy idő után elengedhetetlenné válik [25].

A legutóbbi hatályban volt hazai irányelv szerint az első méhnyakszűrést - citológiai mintavételt - két évvel a nemi élet megkezdése után, de legkésőbb a 21. életévtől javasolt elvégezni; ezen indikáció további alkalmazását a nemzetközi ajánlások alapján javasolt új hazai szakmai irányelv is tartalmazza $[50,51]$. 
Szorgalmazni kell, hogy a fiatal kezdeményezzen szüleivel beszélgetést a szexuális életről. Kiemelendő, hogy a média lehet hasznos információforrás is, de vannak olyan weboldalak, amelyek látogatása nemkívánatos [47].

Legyen megfelelő légkör és idő a konzultáció lebonyolítására, legyen a tájékoztatás teljes körü, ingyenes, érzékeltessük a fiatallal, hogy az ő választása maximálisan figyelembe van véve [48].

Tájékoztatni kell a fiatalokat a mindenkori óvszerhasználat fontosságáról, a dupla védekezésről [49], a sürgősségi fogamzásgátlóról, a kombinált orális fogamzásgátlók nem kontraceptív előnyeiről.

Tudnunk kell azt is, hogy a mentális vagy krónikus betegségekkel küzdő serdülők is ugyanúgy élnek nemi életet, mint egészséges kortársaik, de a védekezés megoldása néha igen nehéz feladat ebben a csoportban [33].

A serdülőt felvilágosítók feladata és felelőssége nagy: hogyan történjen meg az adott felvilágosítás úgy, hogy ne csak a negatív oldalát mutassuk meg, ne riasszuk el őket az orvosoktól, a vizsgálattól. A külföldi irodalmat áttekintve találunk létező irányelveket arra nézve, hogy hogyan vegyük fel az általános anamnézist, a szexuális anamnézist, hogyan készítsünk 15 perc alatt átfogó pszichoszociális helyzetelemzést $[52,53]$. De nemcsak orvosi, hanem oktatási irányelvek, útmutatók is elérhetők, melyek hazai adaptációja hozzá tudna járulni a szexuális nevelés egységes szemléletének kialakításához [22].

$\mathrm{Az}$ eredmények felhívják a figyelmet a reprodukciós élet oktatási, nevelési hiányosságaira, amelynek javítása összetett feladat, megoldásához szükség van a hazai egészségügyi és oktatási rendszer szemléletváltására. A hazai alap- és szakellátásban - háziorvos, gyermekháziorvos, bőrgyógyász, nőgyógyász, gyermeknőgyógyász el kell fogadni és követni a tudományos bizonyítékokon alapuló irányelvek ajánlásait. Több időt kell szánnunk egy-egy páciensre, rákérdezéssel segíteni óket jövetelük céljának megfogalmazásában. A gyermekháziorvosok segítsége elengedhetetlenné válik. A szexuális nevelésben minden olyan egészségügyi dolgozónak részt kell vállalnia, aki a munkája során serdülőkkel találkozik. Ugyancsak elengedhetetlen a szexuális nevelésnek az oktatásba való folyamatos beépítése, kisgyermekkortól egészen a fiatal felnőtt korig.

Anyagi támogatás: A közlemény megírása, illetve a kapcsolódó kutatómunka anyagi támogatásban nem részesült.

Szerzői munkamegosztás: V.-T. A.: A kutatás tervezése, kivitelezése, az eredmények értékelése, a szakirodalom áttekintése, a kézirat összeállítása. N. G.: Az eredmények értékelése, a kézirat összeállítása. P. E.: A kutatás tervezése, statisztikai elemzések, a kézirat összeállítása. A cikk végleges változatát valamennyi szerző elolvasta és jóváhagyta.

Érdekeltségek: A szerzőknek nincsenek érdekeltségeik.

\section{Irodalom}

[1] Inchley J, Currie D, Young T, et al. (eds.) Growing up unequal: gender and socioeconomic differences in young people's health and well-being. Health Behaviour In School-Aged Children (HBSC) Study: International report from the 2013/2014 survey. Health Policy for Children and Adolescents, No. 7. World Health Organization, Geneva, 2016.

[2] Költő A. Sexual behaviour and romantic experiences. In: Németh Á, Költő A. (eds.) Health Behaviour in School-aged Children (HBSC): A WHO-collaborative Cross-National Study, National Report 2014. [Szexuális magatartás és romantikus tapasztalatok. In: Németh Á, Költő A. (szerk.) Egészség és egészségmagatartás iskoláskorban 2014. Az Iskoláskorú gyermekek egészségmagatartása elnevezésú, az Egészségügyi Világszervezettel együttmúködésben megvalósuló nemzetközi kutatás 2014. évi felméréséről készült nemzeti jelentés.] Nemzeti Egészségfejlesztési Intézet, Budapest, 2016; pp. 121-130. [Hungarian]

[3] Sedgh G, Finer LB, Bankole A, et al. Adolescent pregnancy, birth, and abortion rates across countries: levels and recent trends. J Adolesc Health 2015; 56: 223-230.

[4] Abortions. [Terhességmegszakítások.] Központi Statisztikai Hivatal, Budapest, 2018. www.ksh.hu/docs/hun/xftp/idoszaki/ pdf/terhessegmegszl6.pdf [Hungarian]

[5] Hungarian health statistics yearbook, 2016. [Egészségügyi statisztikai évkönyv, 2016.] Központi Statisztikai Hivatal, Budapest, 2017. [Hungarian]

[6] Demographic yearbook, 2016. [Demográfiai évkönyv, 2016.] Központi Statisztikai Hivatal, Budapest, 2017. [Hungarian]

[7] OECD/EU. Health at a Glance: Europe 2016 - State of Health in the EU Cycle. OECD Publishing, Paris, 2016. http://dx.doi. org/10.1787/9789264265592-en

[8] Devosa I, Kozinszky Z, Vanya M, et al. Knowledge of university students in Szeged, Hungary about reliable contraception methods and sexually transmitted diseases. [Szegedi egyetemi hallgatók ismeretei a megbízható fogamzásgátlásról és a szexuális úton terjedő betegségekről.] Orv Hetil. 2016; 157: 539-546. [Hungarian]

[9] Varga-Tóth A, Paulik E. Role of gynecologists in reproductive education of adolescent girls in Hungary. J Obstet Gynaecol Res. 2015; 41: 747-754.

[10] Fergus S, Zimmerman MA, Caldwell CH. Growth trajectories of sexual risk behavior in adolescence and young adulthood. Am J Public Health 2007; 97: 1096-1101.

[11] Poulin C, Graham L. The association between substance use, unplanned sexual intercourse and other sexual behaviours among adolescent students. Addiction 2001; 96: 607-621.

[12] Pénzes M, Czeglédi E, Balázs P, et al. Smoking trajectories among Hungarian adolescents. [Dohányzói életutak magyar serdülók körében.] Orv Hetil. 2017; 158: 67-76. [Hungarian]

[13] Kirby D, Coyle K. School-based programs to reduce sexual risktaking behavior. Child Youth Serv Rev. 1997; 19: 415-436.

[14] Lindberg L, Santelli J, Desai S. Understanding the decline in adolescent fertility in the United States, 2007-2012. J Adolesc Health 2016; 59: 577-583.

[15] Society for Adolescent Health and Medicine. Abstinence-onlyuntil-marriage policies and programs: an updated position paper of the Society for Adolescent Health and Medicine. J Adolesc Health 2017; 61: 400-403.

[16] Thaxton L, Espey E. Family planning American style redux: unintended pregnancy improves, barriers remain. Obstet Gynecol Clin North Am. 2017; 44: 41-56.

[17] School - health promotion - sexual education. [Iskola - egészségfejlesztés - szexedukáció.] Országos Egészségfejlesztési Intézet, Budapest, 2010. Available from: http://regi.oefi.hu/ tanulmany_szex.pdf [accessed: October 20, 2018]. [Hungarian]

[18] The Government decree 110/2012. (VI. 4.) on the issuance, introduction and application of the National Core Curriculum. $[110 / 2012$. (VI. 4.) Korm. rendelet a Nemzeti alaptanterv ki- 
adásáról, bevezetéséről és alkalmazásáról.] Magyar Közlöny 2012; 66: 10635-10847. [Hungarian]

[19] Szilágyi V. Sexual education in Europe. [A szexuális nevelés európai programja.] Available from: http://iskolapszichologiaimodszertani-bazis.elte.hu/dokumentumok/Szilágyi-V.-Aszex.-nevelés-európai-programja-1.pdf [accessed: October 20, 2018]. [Hungarian]

[20] Loeber O, Reuter S, Apter D, et al. Aspects of sexuality education in Europe - definitions, differences and developments. Eur J Contracept Reprod Health Care 2010; 15: 169-176.

[21] Committee Opinion No. 678: Comprehensive sexuality education. American College of Obstetricians and Gynecologists. Obstet Gynecol. 2016; 128: e227-e230.

[22] WHO Regional Office for Europe and BZgA Standards for Sexuality Education in Europe. A framework for policy makers, educational and health authorities and specialists. Federal Centre for Health Education, BZgA, Cologne, 2010. Available from: https://www.oif.ac.at/fileadmin/OEIF/andere_Publikationen/WHO_BZgA_Standards.pdf [accessed: October 20, 2018]. (Hungarian version available from: http://www.szexualpszichologia.hu/who_iranyelvei.html [accessed: October 20, 2018].)

[23] Sober S, Shea JA, Shaber AG, et al. Postpartum adolescents' contraceptive counselling preferences. Eur J Contracept Reprod Health Care 2017; 22: 83-87.

[24] Borsos A. Basics of paediatric gynaecology. In: Papp Z. (ed.) Handbook of gynaecology. [A gyermeknőgyógyászat alapvonalai. In: Papp Z. (szerk.) A nőgyógyászat kézikönyve.] Medicina Könyvkiadó, Budapest, 2016; pp. 239-250. [Hungarian]

[25] Papp Z. Textbook of obstetrics and gynaecology. [A szülészetnőgyógyászat tankönyve. Ötödik kiadás.] Semmelweis Kiadó, Budapest, 2017. [Hungarian]

[26] Major T. Intrauterine contraception in nulliparous women. Resolution of the Professional College of Obstetrics and Gynecology, Assisted Reproductive Section. [Méhen belüli fogamzásgátlás még nem szült nőknél. A Szakmai Kollégium Szülészeti és Nőgyógyászati, Asszisztált Reprodukciós Tagozatának állásfoglalása.] Magy Nőorv L. 2014; 77: 42-44. [Hungarian]

[27] Major T. Contraception in adolescence. In: Papp Z. (ed.): Handbook of gynaecology. [Fogamzásgátlás serdülőkorban. In: Papp Z. (szerk.) A nőgyógyászat kézikönyve.] Medicina Könyvkiadó, Budapest, 2016; pp. 260-264. [Hungarian]

[28] Committee Opinion No. 699: Adolescent pregnancy, contraception, and sexual activity. American College of Obstetricians and Gynecologists. Obstet Gynecol. 2017; 129: el42-el49.

[29] Committee Opinion No. 735: Adolescents and long-acting reversible contraception: implants and intrauterine devices. American College of Obstetricians and Gynecologists. Obstet Gynecol. 2018; 131: el30-el39.

[30] Committee Opinion No. 710: Counseling adolescents about contraception. American College of Obstetricians and Gynecologists. Obstet Gynecol. 2017; 130: e74-e80.

[31] Kaunitz AM. Contraceptive counseling and selection. Available from: https://www.uptodate.com/contents/contraceptivecounseling-and-selection [This topic last updated: Sep 10, 2018] [accessed: October 12, 2018].

[32] Dehlendorf C, Krajewski C, Borrero S. Contraceptive counseling: best practices to ensure quality communication and enable effective contraceptive use. Clin Obstet Gynecol. 2014; 57: 659-673.

[33] Committee on Adolescence. Contraception for adolescents. Pediatrics 2014; 134: el244-el256.

[34] Curtis KM, Tepper NK, Jatlaoui TC, et al. U.S. Medical Eligibility Criteria for Contraceptive Use, 2016. MMWR Recomm Rep. 2016; 65: 1-104.

[35] Francis JK, Gold MA. Long-acting reversible contraception for adolescents: A review. JAMA Pediatr. 2017; 171: 694-701.
[36] Medical eligibility criteria for contraceptive use. Fifth edition. World Health Organization, 2015. Available from: http://apps. who.int/iris/bitstream/10665/181468/1/9789241549158_ eng.pdf [accessed: October 20, 2018].

[37] Mestad R, Secura G, Allsworth JE, et al. Acceptance of longacting reversible contraceptive methods by adolescent participants in the Contraceptive CHOICE Project. Contraception 2011; 84: 493-498.

[38] O’Neil-Callahan M, Peipert JF, Zhao Q, et al. Twenty-fourmonth continuation of reversible contraception. Obstet Gynecol. 2013; 122: 1083-1091.

[39] Gemzell-Danielsson K, Buhling KJ, Dermout SM, et al. A Phase III, single-arm study of LNG-IUS 8, a low-dose levonorgestrel intrauterine contraceptive system (total content $13.5 \mathrm{mg}$ ) in postmenarcheal adolescents. Contraception 2016; 93: 507-512.

[40] Diedrich JT, Klein DA, Peipert JF. Long-acting reversible contraception in adolescents: a systematic review and meta-analysis. Am J Obstet Gynecol. 2017; 216: 364.el-364.el2.

[41] Gemzell-Danielsson K, Inki P, Heikinheimo O. Safety and efficacy of the levonorgestrel-releasing intrauterine system: recent insights. Expert Rev Obstet Gynecol. 2013; 8: 235-247.

[42] Caddy S, Yudin MH, Hakim J, et al. Best practices to minimize risk of infection with intrauterine device insertion. J Obstet Gynaecol Can. 2014; 36: 266-274.

[43] Sufrin CB, Postlethwaite D, Armstrong MA, et al. Neisseria gonorrhoea and Chlamydia trachomatis screening at intrauterine device insertion and pelvic inflammatory disease. Obstet Gynecol. 2012; 120: 1314-1321.

[44] Arisi E, Bruni V, Di Spiezio Sardo A, et al. Italian guidelines on the effective and appropriate use of intrauterine contraception. Ital J Gynaecol Obstet. 2014; 26: 7-20.

[45] Pritt NM, Norris AH, Berlan ED. Barriers and facilitators to adolescents' use of long-acting reversible contraceptives. J Pediatr Adolesc Gynecol. 2017; 30: 18-22.

[46] Tomlin K, Bambulas T, Sutton M, et al. Motivational interviewing to promote long-acting reversible contraception in postpartum teenagers. J Pediatr Adolesc Gynecol. 2017; 30: 383-388.

[47] Breuner CC, Mattson G, Committee on Adolescence, Committee on Psychosocial aspects of Child and Family Health. Sexuality Education for Children and Adolescents. Pediatrics 2016; 138: e20161348.

[48] Sexual and reproductive health care: a position paper of the Society for Adolescent Health and Medicine. J Adolesc Health 2014; 54: 491-496.

[49] Raidoo S, Kaneshiro B. Contraception counseling for adolescents. Curr Opin Obstet Gynecol. 2017; 29: 310-315.

[50] Koiss R, Boncz I, Hernádi Z, et al. Proposal for the modernization of cervical screening procedure in Hungary. [Javaslat a hazai méhnyakszűrési eljárásrend korszerűsítésére.] Orv Hetil. 2017; 158: 2062-2067. [Hungarian]

[51] Póka R. Cervical screening. International overview and recommendation for a new Hungarian guideline. [Méhnyakszűrés. Nemzetközi körkép és javaslat a hazai irányelvek fejlesztésére.] Magy Nőorv L. 2018; 81: 38-46. [Hungarian]

[52] Doukrou M, Segal TY. Fifteen-minute consultation: communicating with young people - how to use HEEADSSS, a psychosocial interview for adolescents. Arch Dis Child Educ Pract Ed. 2018; 103: 15-19.

[53] Brook G, Bacon L, Evans C, et al. 2013 UK national guideline for consultations requiring sexual history taking. Clinical Effectiveness Group, British Association for Sexual Health and HIV. Int J STD AIDS 2014; 25: 391-404.

(Paulik Edit dr., Szeged, Dóm tér 10., 6720 e-mail: paulik.edit@med.u-szeged.hu) 